\title{
Розробка апаратів для первинної термічної обробки і холодильного зберігання харчових продуктів
}

\author{
T. І. Гратій \\ ${ }^{1-2}$ Одеська національна академія харчових технологій, вул. Канатна, 112, Одеса, 65039, Україна \\ $\triangle$ e-mail: ${ }^{2}$ titlov1959@gmail.com \\ ORCID: ${ }^{1}$ https://orcid.org/0000-0002-3525-8410; ${ }^{2}$ https://orcid.org/0000-0003-1908-5713
}

Проведено експериментальні дослідження комбінованих холодильних агрегатів абсорбиійного типу (АХА) з додатковою нагрівальною камерою (ДНК), яка забезпечує теплову та холодильну обробку харчових продуктів у побуті. Для забезпечення теплового зв'язку між теплорозсіювальними елементами АХА (дефлегматором) використовується двофазний випарний термосифон (ДФТС). Показано, що теплова потужність, яка відводиться у прочесі проведення випробувань АХА з ДФТС, закріпленого на підйомній магістралі дефлегматора, не перевищувала 7 Bm, а в середньому становила $4 . . .5$ Bm; величини теплового потоку, що відводиться з дефлегматора АХА за допомогою ДФТС, достатньо тільки для підтримки в ДНК температури на рівні $50{ }^{\circ} \mathrm{C}$; для підтримки у ДНК рівня температур $70{ }^{\circ} \mathrm{C}$ і $100{ }^{\circ} \mathrm{C}$ потрібні додаткові енерговитрати; величина додаткових енерговитрат для $70{ }^{\circ} \mathrm{C}$ становить 3,5 Bm, а для $100{ }^{\circ} \mathrm{C}-8,7 \mathrm{Bm}$, при цьвому добові енерговитрати холодильника зростуть відповідно на 4,9\% і 12,3\%; за повного використання теплоти дефлегмації для обігріву ДНК можливе гарантоване забезпечення ї̈ теплових режимів у діапазоні температур $50 \ldots 100{ }^{\circ} \mathrm{C}$; у разі використання у якості робочого середовища ДНК повітря виникають проблеми при теплопередаванні від конденсатора ДФТС до внутрішнього об'єму камери - у иьому випадку необхідно підтримувати перепад температур між нагрівальною панеллю і повітрям в ДНК близько $25 . . .35{ }^{\circ} \mathrm{C}$ а величина панелі повинна становити не менше 0,200×0,285 м; у разі використання води у якості робочого середовища ДНК дочільно використовувати нагрівальні панелі заввишки 0,2 м, шириною 0,02...0,03 м, а для інтенсифікації процесів теплопередавання при нагріванні води нагрівальну панель необхідно розтамовувати в нижній частині ДНК; у разі використання повітря в ДНК його охолодження через втрату тепла до навколишнього повітря йде в 32 рази швидше, ніж при використанні води при початковій температурі $50{ }^{\circ} \mathrm{C}$ і в 11 раз швидще при початковій температурі $70{ }^{\circ} \mathrm{C}$.

Ключові слова: Абсорбційний холодильний агрегат; Додаткова нагрівальна камера; Двофазний випарний термосифон; Утилізація скидного тепла холодильного иџклу; Експериментальні дослідження

\section{doi: https://doi.org/10.15673/ret.v57i3.2163}

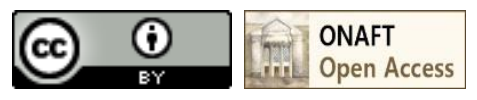

\section{1. Вступ}

На сучасному етапі економіки простежується тенденція збільшення частки приватної власності в усіх видах виробництва. Приватизація землі веде до організації безлічі дрібних ферм та сімейних підприємств у сільському господарстві та харчовій промисловості. Така структура виробництва зумовлює необхідність створення специфічного обладнання для первинної обробки та зберігання харчових продуктів. Дотримання температурних та вологісних режимів дозволить виключити неви- 
правдано високі втрати сировини та напівфабрикатів на стадії зберігання та транспортування. У зв'язку з цим створення універсального обладнання для первинної обробки харчових продуктів із застосуванням енергозберігаючих технологій $\epsilon$ важливим та актуальним завданням.

Вирішення цього завдання можливе шляхом виробництва холодильних агрегатів 3 додатковою нагрівальною камерою, для роботи яких не потрібно значних витрат електроенергії, а джерелом теплової потужності може бути будь-який енергоносій, наприклад, природний газ, гас, гаряча вода, сонячна енергія [1-5].

Термодинамічний та ексергетичний аналіз холодильного циклу абсорбційних холодильних агрегатів (AХА) показав практичну доцільність використання скидного тепла 3 теплонавантажених елементів для підтримки температурного режиму додаткової нагрівальної камери [6].

Утилізація теплоти можлива за допомогою вертикальних випарних термосифонів, зона випаровування яких знаходиться у тепловому зв'язку із теплонавантаженими елементами АХА, а зона конденсації розташована в додатковій камері нагрівання, яка встановлюється на верхній кришці апарату [7-12].

Передбачено два варіанти виконання додаткової нагрівальної камери: для підігріву рідин та технологічної обробки харчових продуктів [1].

У процесі експлуатації даного апарату забезпечується низькотемпературне зберігання м'ясомолочних продуктів при двох рівнях температур мінус $16{ }^{\circ} \mathrm{C}$ та плюс $5{ }^{\circ} \mathrm{C}$ і паралельно - технологічна теплова обробка в температурному діапазоні $25 \ldots 100{ }^{\circ} \mathrm{C}$, при якій може бути отриманий новий сушений, в'ялений або зброджений продукт.

В даний час під новий агрегат розроблено технології короткочасної (температура $72 \ldots 75^{\circ} \mathrm{C} 3$ витримкою $20 \mathrm{xв})$ та тривалої $\left(63 \ldots 65{ }^{\circ} \mathrm{C}\right.$ з витримкою 30 хв) пастеризації молока, виробництва кисломолочних продуктів [13]. Для сквашування використовують мікроорганізми, що знаходяться в сирому молоці, або вводять чисті культури мікроорганізмів пастеризоване молоко.

\section{2. Експериментальна перевірка моделей агрегатів 3 додатковою нагрівальною ка- мерою}

Метою дослідження було вивчення можливості утилізації теплоти, що виділяються при ро- боті серійного холодильника АШ-150 для забезпечення теплового режиму додаткової нагрівальної камери (ДНК), що працює в діапазоні температур $30 \ldots 100^{\circ} \mathrm{C}$.

Завдання досліджень - проведення випробувань серійного агрегату АШ-150 у складі шафи, а також проведення випробувань серійного агрегату АШ-150 у складі шафи 3 двофазним випарним термосифоном (ДФТС, що забезпечує теплові режими ДНК).

Випробування холодильника проводилися за апробованою методикою Васильківського заводу холодильників [14].

Умови проведення випробувань та результати наведено в табл. 1 та на рис. 1-4.

На рис. 1 показана схема розташування термопар в об'ємі низькотемпературного відділення (НТВ) та холодильної камери (ХК).

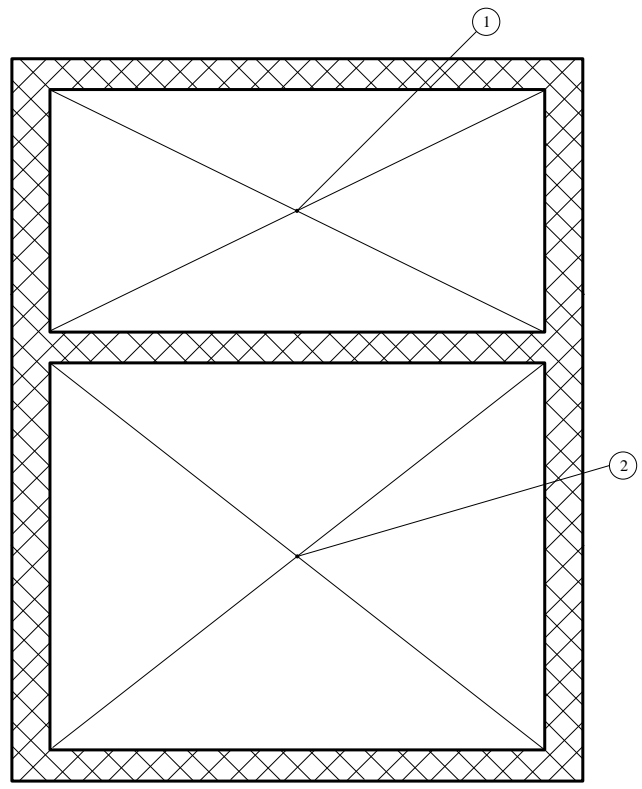

Рисунок 1 - Схема розташування термопар у НТВ та холодильній камері

На рис. 2 наведена схема розташування термопар у характерних точках AXA.

На рис. 3 показано розташування термопар на генераторі AXА у разі використання ДФТС, що працює на ДНК.

На рис. 4 представлена конструкція ДФТС. Кріплення ДФТС здійснювалося за допомогою хомутів до підйомної магістралі дефлегматора АХА.

Аналіз представлених у таблиці результатів випробувань показує, що встановлення на підйомній магістралі дефлегматора випарної зони ДФТС, що супроводжується додатковим тепловідведенням у навколишнє середовище, не вплинуло на роботу випарника AXA. 


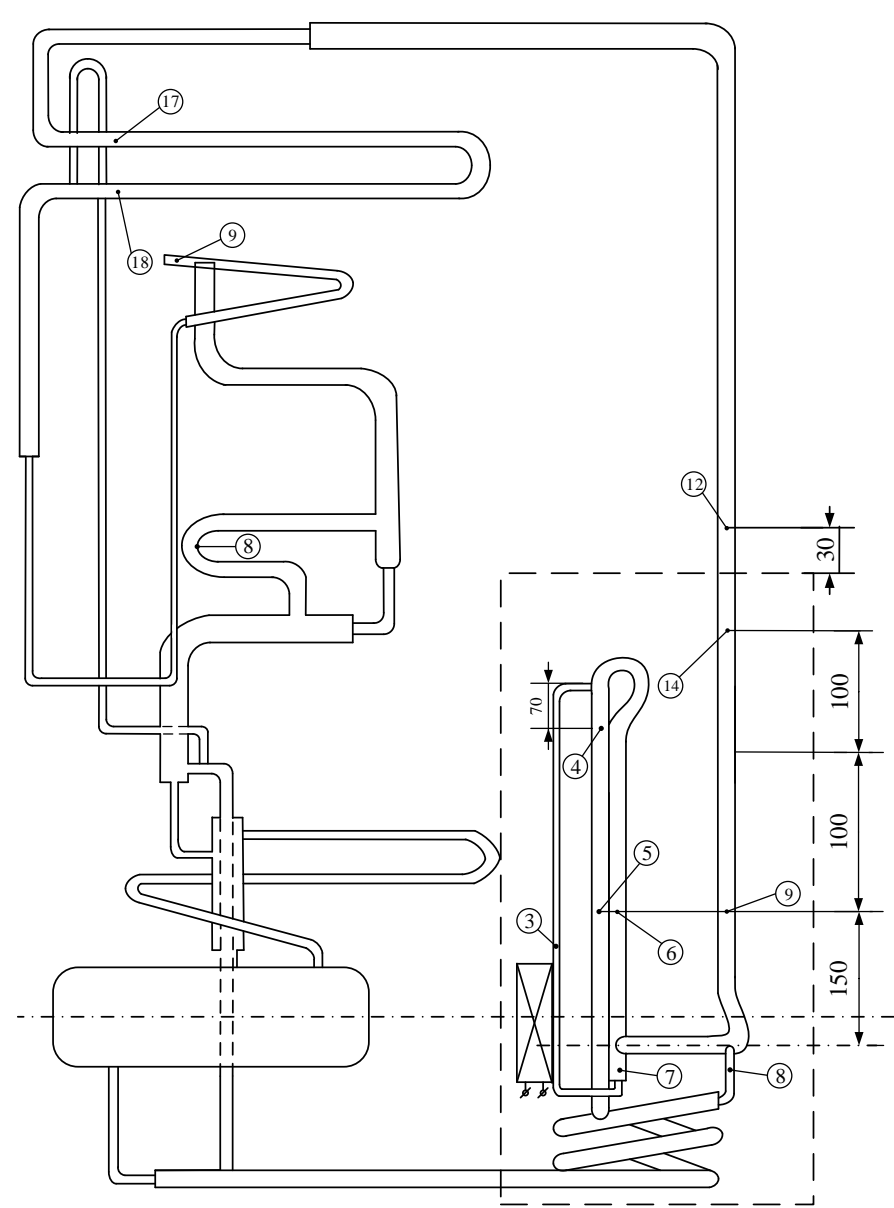

Рисунок 2 - Схема розташування термопар на елементах $A X A$

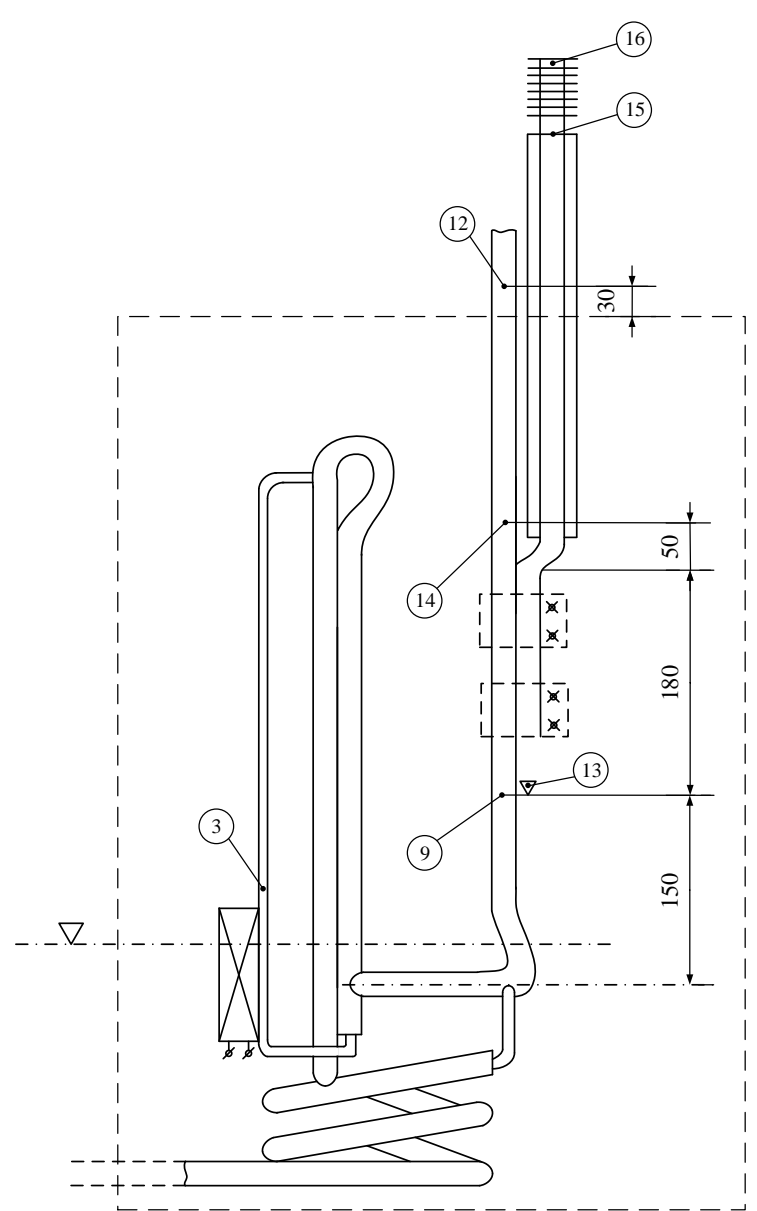

Рисунок 3 - Схема розташування термопар на генераторі-термосифоні АХА та ДФТС

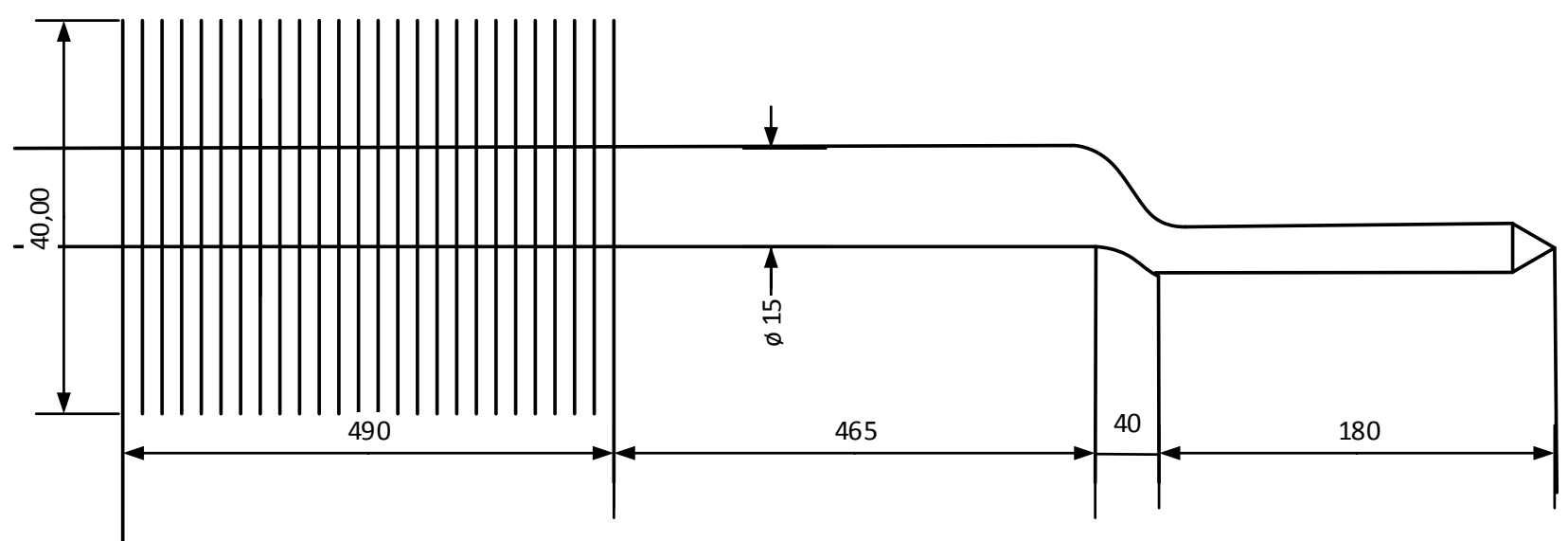

Рисунок 4 - Конструкиія ДФТС: товщина ребра - 0,3 мм; матеріал ребра - алюміній; кількість ребер - 144 шт; матеріал корпусу - мідь; теплоносій-вода

Коливання температур як у випарнику АХА, так і в обсягах НТВ та ХК не перевищувало $1,5 \ldots 2,0{ }^{\circ} \mathrm{C}$. При цьому коливання температур визначалися лише відповідно до коливань температури навколишнього повітря.

Збільшення теплової потужності нагрівача 3 110 Вт до 132 Вт також не призвело до суттєвого зниження температур на випарнику та камерах. Спостерігалося зниження на $1 . . .2{ }^{\circ} \mathrm{C}$.
Проведено оцінку втрат тепла 3 ділянки дефлегматора, пов'язаного з випарником ДФТС.

Для аналізу використано чисельні значення температур, що вимірюються термопарами № 9 та №14.

При визначенні теплової потужності зазначеної ділянки дефлегматора величину холодильної потужності випарника AXА приймемо $25 \mathrm{BT} ; 30$ Вт; 35 Вт; 40 Вт. 
Таблиця 1 - Умови проведення випробувань

\begin{tabular}{|c|c|c|c|c|c|c|c|c|c|}
\hline \multirow{2}{*}{$\begin{array}{l}\text { №№ } \\
\text { 3/П }\end{array}$} & \multirow{2}{*}{$\begin{array}{c}\text { Найменування пара- } \\
\text { метрів }\end{array}$} & \multirow{2}{*}{$\begin{array}{c}\text { Номери } \\
\text { термопар } \\
\text { за рис.1-3 }\end{array}$} & \multicolumn{7}{|c|}{ ВАРІАНТИ } \\
\hline & & & I & II & III & IV & $\mathrm{V}$ & VI & VII \\
\hline 1 & 2 & 3 & 4 & 5 & 6 & 7 & 8 & 9 & 10 \\
\hline & Температура, ${ }^{\circ} \mathrm{C}$ & & & & & & & & \\
\hline 1. & - у центрі обсягу НТВ & 1 & $-16,2$ & $-15,2$ & $-15,1$ & $-16,0$ & $-16,8$ & $-15,0$ & $-15,0$ \\
\hline 2. & $\begin{array}{l}\text { - у центрі об'єму холо- } \\
\text { дильної камери }\end{array}$ & 2 & 0,0 & 0,8 & 1,1 & $-0,3$ & $-0,9$ & 1,1 & 1,3 \\
\hline 3. & $\begin{array}{l}\text { - термосифона після } \\
\text { нагрівача }\end{array}$ & 3 & 176,0 & 174,0 & 174,0 & 174,0 & 182,0 & 174,0 & 174,0 \\
\hline 4. & $\begin{array}{l}\text { - на виході } з \text { термоси- } \\
\text { фону }\end{array}$ & 4 & - & - & - & - & - & - & 169,0 \\
\hline 5. & $\begin{array}{l}\text { - слабкого розчину на } \\
\text { виході з термосифону }\end{array}$ & 5 & - & - & - & - & - & - & 161,0 \\
\hline 6. & $\begin{array}{l}\text { - відпускної магістралі } \\
\text { дефлегматора }\end{array}$ & 6 & - & - & - & - & - & - & 166,0 \\
\hline 7. & $\begin{array}{l}\text { - міцного розчину на } \\
\text { вході до термостату }\end{array}$ & 7 & - & - & - & - & - & - & 137,0 \\
\hline 8. & $\begin{array}{l}\text { - міцного розчину після } \\
\text { рідинного теплообмін- } \\
\text { ника }\end{array}$ & 8 & - & - & - & - & - & - & 117,0 \\
\hline 9. & - підйомної магістралі & 9 & 138,0 & 118,5 & 118,5 & 118,5 & 125,0 & 120,5 & 117,0 \\
\hline 10. & дефлегматора, вкритої & 10 & 137,0 & - & - & - & - & - & - \\
\hline 11. & ізоляційним кожухом & 11 & 129,0 & - & - & - & - & - & - \\
\hline 12. & $\begin{array}{l}\text { - підйомної магістралі } \\
\text { дефлегматора за ізо- } \\
\text { ляційним кожухом }\end{array}$ & 12 & 101,0 & 72,5 & 71,5 & 74,5 & 81,0 & 87,0 & - \\
\hline 13. & $\begin{array}{l}\text { - зони випаровування } \\
\text { ДФТС }\end{array}$ & 13 & 78,0 & 77,5 & 79,8 & 83,0 & 81,0 & 137,0 & - \\
\hline 14. & $\begin{array}{l}\text { - підйомної магістралі } \\
\text { дефлегматора, вкритої } \\
\text { ізоляційним кожухом }\end{array}$ & 14 & - & 93,0 & 93,0 & 94,0 & 103,0 & 99,0 & - \\
\hline 15. & $\begin{array}{l}\text { - входу конденсатора } \\
\text { ДФТС }\end{array}$ & 15 & - & 61,0 & 61,0 & 63,0 & 64,0 & 64,5 & - \\
\hline 16. & $\begin{array}{l}\text { - кінця конденсатора } \\
\text { ДФТС }\end{array}$ & 16 & - & 34,0 & 57,0 & 57,0 & 59,0 & 58,0 & - \\
\hline 17. & $\begin{array}{l}\text { - на вході в конденса- } \\
\text { тор АХА }\end{array}$ & 17 & - & 47,0 & 47,5 & 47,0 & 47,5 & 47,5 & 47,0 \\
\hline 18. & $\begin{array}{l}\text { на виході з конденсато- } \\
\text { ра АХА }\end{array}$ & 18 & - & 39,5 & 39,5 & 38,0 & 42,5 & 40,0 & 38,0 \\
\hline 19. & - початку кипіння & 19 & $-22,0$ & $-20,8$ & $-20,8$ & $-21,8$ & $-22,2$ & $-20,5$ & $-21,8$ \\
\hline 20. & - кінця кипіння & 20 & $-7,9$ & $-7,0$ & $-6,9$ & $-8,0$ & $-9,0$ & $-6,8$ & $-6,2$ \\
\hline 21. & $\begin{array}{l}\text { - парогазової суміші на } \\
\text { виході з абсорбера }\end{array}$ & 21 & - & 47,5 & 47,5 & 46,0 & 49,0 & 48,5 & - \\
\hline 22. & $\begin{array}{l}\text { - парогазової суміші на } \\
\text { вході до абсорберу }\end{array}$ & 22 & - & 46,0 & 45,5 & 45,0 & 47,0 & 46,0 & - \\
\hline
\end{tabular}




Продовження таблиці 1
\begin{tabular}{|c|c|c|c|c|c|c|c|c|c|}
\hline \multirow{2}{*}{$\begin{array}{c}\text { №o } \\
3 / \Pi\end{array}$} & $\begin{array}{c}\text { Найменування пара- } \\
\text { метрів }\end{array}$ & $\begin{array}{c}\text { Номери } \\
\text { термопар } \\
\text { за рис.1-3 }\end{array}$ & \multicolumn{7}{|c|}{ ВАРІАНТИ } \\
\cline { 4 - 12 } & & 3 & 4 & 5 & 6 & 7 & 8 & 9 & 10 \\
\hline 23. & - довкілля & 23 & 31,9 & 31,5 & 32,2 & 31,8 & 31,5 & 32,2 & 31,5 \\
\hline 24. & $\begin{array}{l}\text { теплова потужність } \\
\text { нагрівача генератора- } \\
\text { термосифона АХА }\end{array}$ & - & 110,0 & 110,0 & 110,0 & 110,0 & 132,0 & 110,0 & 110,0 \\
\hline
\end{tabular}

Примітка: 1. У VI варіанті підйомна магістраль дефлегматора, щя знаходиться за межами ізоляиійного кожуха була вкрита ізоляцією (базальт) до початку конденсатора. 2. V VII варіанті з дефлегматора знято теплову трубу та ізоляцію з підйомної магістралі, щзо знаходиться за межами ізоляційного кожуха.

Кратність циркуляції флегми визначимо із формули:

$$
R=\frac{\xi_{1}-\xi_{2}}{\xi_{2}-\xi_{3}}
$$

де $\xi_{1}$ - масова частка пари аміаку у водоаміачній паровій суміші на кінці заданої ділянки дефлегматора, кг/кг;

$\xi_{2}-$ масова частка пари аміаку у водоаміачній паровій суміші на вході заданої ділянки дефлегматоpa, кг/кг;

$\xi_{3}$-масова частка рідкого аміаку у водоаміачному розчині, рівноважна масовій частці пари аміаку на вході заданої ділянки дефлегматора, кг/кг.

Питома теплова потужність заданої ділянки дефлегматора:

$$
q_{R}=R\left(i_{2}-i_{3}\right)+i_{2}-i_{1},
$$

де $i_{2}$ - ентальпія пари водоаміачної парової суміші на вході, кДж/кг;

$i_{3}$ - ентальпія рідини водоаміачного розчину на вході, кДж/кг;

$i_{1}$ - ентальпія пари водоаміачної парової суміші на виході, кДж/кг.

Масова витрата аміаку:

$$
G=\frac{Q_{0}}{\bar{r}},
$$

де $\bar{r}$ - середня теплота пароутворення аміаку, Дж/кг.
У діапазоні робочих температур випаровування $-22 \ldots-7^{\circ} \mathrm{C}$ ця величина становить 1310 кДж/кг [15].

Теплова потужність дефлегматора:

$$
Q_{R}=q_{R} \cdot G
$$

Термодинамічні характеристики аміаку та водоаміачної суміші визначалися з $i$ - $\xi$ - діаграми для водоаміачної суміші та таблиць [15].

Результати розрахунку теплового режиму дефлегматора зведені у таблиці 2.

Аналіз результатів, наведених у табл. 2, показує, що теплова потужність, що відводиться 3 ділянки дефлегматора, пов'язаного із зоною випаровування ДФТС, не перевищувала 7 Вт, а в середньому становила $4 . . .5$ Вт.

Проведемо аналіз оцінки теплового потоку, що розсіюється з конденсатора ДФТС.

Середня температура конденсатора становить $60{ }^{\circ} \mathrm{C}$. Перепад температур із навколишнім повітрям близько $30^{\circ} \mathrm{C}$.

Середній коефіцієнт тепловіддавання можна оцінити за формулою джерела [16]:

$$
N u_{\mathrm{p}, l}=0,75\left(G r_{\mathrm{p}, l} \cdot \operatorname{Pr}\right)^{0,25} \cdot\left(\frac{\operatorname{Pr}_{\mathrm{p}}}{\operatorname{Pr}_{\mathrm{cr}}}\right)^{0,25}
$$

Визначальна температура - температура рідини $t_{\mathrm{p}}=30^{\circ} \mathrm{C}$.

Визначальний розмір - висота конденсатора ДФТС - 0,49 м.

Температура стінки конденсатора ДФТС $t_{\text {cr }}=60{ }^{\circ} \mathrm{C}$.

Теплофізичні характеристики повітря при температурі $t_{\mathrm{p}}=30^{\circ} \mathrm{C}$. 
Таблиця 2 - Результати розрахунку теплового режиму дефлегматора

\begin{tabular}{|c|c|c|c|c|c|c|}
\hline \multirow{2}{*}{$\begin{array}{l}\text { №№ } \\
\text { p/ח }\end{array}$} & \multirow{2}{*}{ Найменування параметрів } & \multicolumn{5}{|c|}{ ВАРІАНТИ } \\
\hline & & II & III & IV & $\mathrm{V}$ & VI \\
\hline 1. & $\begin{array}{l}\text { Температура підйомної магістралі } \\
\text { дефлегматора, вкритої ізоляційним } \\
\text { кожухом (термопара №9), }{ }^{\circ} \mathrm{C}\end{array}$ & 118,5 & 118,5 & 118,5 & 125 & 120,5 \\
\hline 2. & (термопара №14), ${ }^{\circ} \mathrm{C}$ & 93,0 & 93,0 & 94,0 & 103,0 & 99,0 \\
\hline 3. & $\xi_{1}, \kappa \Gamma / \kappa \Gamma$ & 0,980 & 0,980 & 0,979 & 0,967 & 0,973 \\
\hline 4. & $\xi_{2}, \kappa \Gamma / \kappa \Gamma$ & 0,934 & 0,934 & 0,934 & 0,916 & 0,931 \\
\hline 7. & $i_{3}$, кДж/кг & 772 & 772 & 772 & 812 & 786 \\
\hline 5. & $\xi_{3}, \kappa г / \kappa \Gamma$ & 0,342 & 0,342 & 0,342 & 0,316 & 0,336 \\
\hline 6. & $i_{2}$, кДж/кг & 1981 & 1981 & 1981 & 2021 & 1993 \\
\hline 8. & $i_{1}$, кДж/кг & 1860 & 1860 & 1864 & 1902 & 1884 \\
\hline 9. & $R$, кг/кг & 0,078 & 0,078 & 0,076 & 0,085 & 0,071 \\
\hline 10. & $q_{R}$, кДж/кг & 215,3 & 215,3 & 208,9 & 221,8 & 194,2 \\
\hline \multicolumn{7}{|c|}{ Холодильна потужність - 25 Вт } \\
\hline 11. & $G \cdot 10^{5}$ кг/с & 1,91 & 1,91 & 1,91 & 1,91 & 1,91 \\
\hline 12. & $Q_{R}, \mathrm{BT}$ & 4,11 & 4,11 & 3,99 & 4,24 & 3,71 \\
\hline \multicolumn{7}{|c|}{ Холодильна потужність -30 Вт } \\
\hline 13. & $G \cdot 10^{5}$ кг/с & 2,29 & 2,29 & 2,29 & 2,29 & 2,29 \\
\hline 14. & $Q_{R}, \mathrm{BT}$ & 4,93 & 4,93 & 4,78 & 5,08 & 4,45 \\
\hline \multicolumn{7}{|c|}{ Холодильна потужність - 35 Вт } \\
\hline 15. & $G \cdot 10^{5}$ кг/с & 2,67 & 2,67 & 2,67 & 2,67 & 2,67 \\
\hline 16. & $Q_{R}, \mathrm{BT}$ & 5,75 & 5,75 & 5,58 & 5,93 & 5,19 \\
\hline \multicolumn{7}{|c|}{ Холодильна потужність - 40 Вт } \\
\hline 17. & $G \cdot 10^{5}$ кг/с & 3,05 & 3,05 & 3,05 & 3,05 & 3,05 \\
\hline 18. & $Q_{R}, \mathrm{BT}$ & 6,57 & 6,57 & 6,38 & 6,77 & 5,92 \\
\hline
\end{tabular}

$$
\beta=\frac{1}{T_{\mathrm{p}}}=\frac{1}{273+30}=3,30 \cdot 10^{-3} 1 / \mathrm{K}
$$

$v_{\mathrm{p}}=16 \cdot 10^{-6} \mathrm{M}^{2} / \mathrm{c} ; \quad \lambda_{\mathrm{p}}=0,0267 \mathrm{BT} / \mathrm{M} \cdot \mathrm{K} ; \quad \operatorname{Pr}_{\mathrm{p}}=0,701$.

При $t_{\mathrm{cT}}=60{ }^{\circ} \mathrm{C}, \mathrm{Pr}_{\mathrm{cT}}=0,698$

$$
\begin{aligned}
& \overline{N u}_{\mathrm{p}, l}=0,75 \frac{9,8 \cdot 3,3 \cdot 10^{-3} \cdot(60-30) \cdot 0,49^{3}}{\left(16 \cdot 10^{-6}\right)^{2}} \times \\
& \times 0,701^{0,25} \cdot\left(\frac{0,701}{0,698}\right)^{0,25}=99,83
\end{aligned}
$$

$$
\begin{gathered}
\bar{\lambda}=\overline{N u}_{\mathrm{p}, l} \cdot \frac{\lambda_{\mathrm{p}}}{l} \\
\bar{\lambda}=99,83 \frac{0,0267}{0,49}=5,44 \mathrm{BT} / \mathrm{M}^{2} \cdot \mathrm{K} .
\end{gathered}
$$

Поверхня конденсатора ДФТС

$F_{\mathrm{K}}=\pi \cdot D_{\mathrm{K}} \cdot l=3,14 \cdot 0,018 \cdot 0,49=0,0278 \mathrm{~m}^{2}$.

Тепловий потік з конденсатора ДФТС до навколишнього повітря:

$$
Q_{\mathrm{\kappa}}=\bar{\alpha} \cdot F_{\mathrm{\kappa}} \cdot\left(t_{\mathrm{cr}}-t_{\mathrm{cep}}\right)
$$




$$
Q_{\mathrm{\kappa}}=5,44 \cdot 0,0278 \cdot(60-30)=4,5 \text { Вт. }
$$

Із розрахунків видно, що величини теплових потоків на дефлегматорі AXA i конденсаторі ДФТС можна порівняти, тобто баланс дотримується.

Оцінимо необхідні витрати енергії для роботи ДНК.

Схема ДНК із конструктивними розмірами наведена на рис. 5.

Матеріал ізоляції - пінополіуретан (ППУ) 3 коефіцієнтом теплопровідності 0,02 Вт/м ·К.

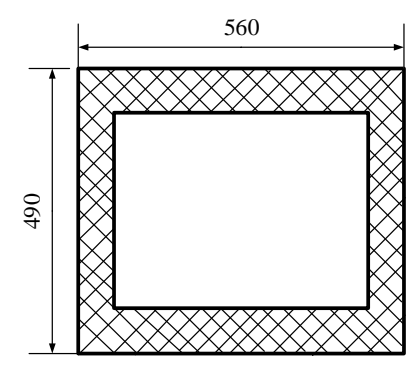

a)

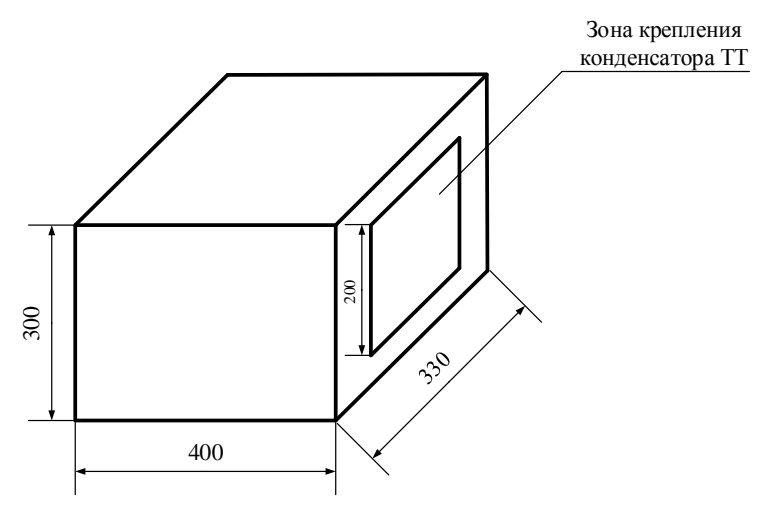

б)

Рисунок 5 - Схема додаткової нагрівальної камери:а) розріз; б) внутрішні розміри

Розрахуємо мінімальну, середню і максимальну теплову потужність, необхідну для подавання в ДНК для підтримки температури повітря $50{ }^{\circ} \mathrm{C}, 70{ }^{\circ} \mathrm{C}$ і $100{ }^{\circ} \mathrm{C}$, відповідно.

Температуру повітря у приміщенні приймаємо $20^{\circ} \mathrm{C}$. Внутрішня теплорозсіювальна поверхня ДНК.

$$
F_{\text {днК }}=(0,4+0,33) \cdot 2 \cdot 0,3+0,4 \cdot 0,33 \cdot 2=0,702 \mathrm{~m}^{2} .
$$

Мінімальний тепловий потік із ДНК до навколишнього повітря

$$
Q_{\text {min }}=\frac{\lambda_{\text {iз }}}{\delta_{\text {iз }}} \cdot F_{\text {днК }} \cdot \Delta t,
$$

Товщина ізоляції із ППУ $-0,08 \mathrm{M}$.

$$
Q_{\text {min }}=\frac{0,02}{0,08} \cdot 0,702 \cdot(50-20)=5,3 \text { Вт. }
$$

Середній тепловий потік із ДНК до навколишнього повітря

$$
Q_{\text {cep }}=\frac{0,02}{0,08} \cdot 0,702 \cdot(70-20)=8,8 \text { Вт. }
$$

Максимальний тепловий потік із ДНК до навколишнього повітря

$$
Q_{\text {макс }}=\frac{0,02}{0,08} \cdot 0,702 \cdot(100-20)=14,0 \text { Вт. }
$$

Таким чином, тепловий потік, що відводиться від ділянки дефлегматора ДФТС може забезпечити тільки роботу в режимі мінімального теплового потоку, тобто підтримувати температуру повітря ДНК на рівні $50{ }^{\circ} \mathrm{C}$.

Для підтримки в камері температур близько $70{ }^{\circ} \mathrm{C}$ і $100{ }^{\circ} \mathrm{C}$ потрібні додаткові енерговитрати, наприклад, додаткового електронагрівача.

Оцінимо додаткові енерговитрати для роботи в режимі підігріву повітря в ДНК.

Для $70{ }^{\circ} \mathrm{C}$ величина додаткових енерговитрат має становити $3,5 \mathrm{BT}$, а $100{ }^{\circ} \mathrm{C}-8,7$ Вт. Тоді добові витрати становитимуть:

$$
\begin{aligned}
& E_{\text {доб(1) }}=0,084 \text { кВт } \cdot \text { год }\left(t_{\mathrm{\kappa}}=70^{\circ} \mathrm{C}\right) ; \\
& E_{\text {доб(2) }}=0,209 \mathrm{\kappa ВТ} \cdot \text { год }\left(t_{\mathrm{\kappa}}=100^{\circ} \mathrm{C}\right) .
\end{aligned}
$$

При добовому споживанні енергії холодильником $E=1,7$ кВт.год, це становитиме $4,9 \%$ i $12,3 \%$, відповідно.

Одним із варіантів зниження енерговитрат при роботі додаткового електронагрівача може бути максимальний відбір теплової потужності з дефлегматора AXA.

Відбір тепла повинен здійснюватися як з підйомної, так і з опускної магістралі дефлегматора.

Використовуючи формули 1-4, здійснимо розрахунок максимальної теплової потужності дефлегматора АХА без ДФТС (Варіант VII). 
Температура на вході $-169^{\circ} \mathrm{C}$.

На вході (в ізоляційному корпусі) $-117^{\circ} \mathrm{C}$.

Параметри пари: $\xi_{1}=0,950$ кг/кг; $\xi_{2}=0,644$ кг/кг; $\xi_{3}=0,141$ кг $/ \kappa г ; i_{1}=1978$ кДж/кг; $i_{2}=2405$ кДж/кг; $i_{3}=1070$ кДж/кг.

Кратність циркуляції

$$
R=\frac{0,95-0,644}{0,644-0,141}=0,608 \text { кг } / \kappa \Gamma .
$$

Питома теплова потужність дефлегматора AXA

$Q_{R}=0,608(2405-1070)+2405-1978=1239$ кДж/кг.

Тоді теплова потужність дефлегматора складе: 23,7 Вт, 28,4 Вт, 33,1 Вт, 37,8 Вт, відповідно при холодильних потужностях випарника АХA
$25 \mathrm{BT}, 30$ Вт, 35 Вт, 40 Вт.

Таким чином, при повному відведенні тепла 3 дефлегматора ДНК можливо гарантоване забезпечення його теплового режиму.

При проектуванні ДНК особливу увагу слід приділити питанню теплопередавання між конденсатором ДНК та внутрішнім обсягом ДНК.

Визначимо необхідну величину нагрівальної панелі, яка перебуває у контакті з конденсатором ДФТС. Висоту нагрівальної панелі приймемо 0,2 м.

Розрахунок коефіцієнтів тепловіддавання проведемо за формулою (5).

У якості робочого тіла ДНК візьмемо воду і повітря. Перепадом температур між нагрівальною панеллю та об'ємом ДНК варіюватимемо в діапазоні $5 . . .35^{\circ} \mathrm{C}$.

Результати розрахунків зведено до таблиці 3.

Таблиця 3 - Розрахунок нагрівальних панелей ДНК

\begin{tabular}{|c|c|c|c|c|c|c|c|c|}
\hline \multirow{6}{*}{ ПАРАМЕТРИ } & \multicolumn{8}{|c|}{ Робоче тіло ДНК } \\
\hline & \multicolumn{4}{|c|}{ Повітря } & \multicolumn{4}{|c|}{ Вода } \\
\hline & \multicolumn{8}{|c|}{ Перепад температур ${ }^{\circ} \mathrm{C}$} \\
\hline & 5 & 15 & 25 & 35 & 5 & 15 & 25 & 35 \\
\hline & \multicolumn{8}{|c|}{ Температура в об'ємі ДНК $-50^{\circ} \mathrm{C}$} \\
\hline & \multicolumn{8}{|c|}{ Втрати тепла через ізоляцію - 5,3 Вт } \\
\hline $\begin{array}{l}\text { 1. Коефіцієнт тепловіддавання } \\
\text { від нагрівальної панелі до ро- } \\
\text { бочого тіла ДНК, Вт/м² } / \text { К }\end{array}$ & 4,3 & 5,6 & 6,3 & 6,9 & 515 & 676 & 768 & 835 \\
\hline $\begin{array}{l}\text { 2. Необхідна поверхня панелі, } \\
\text { м²}^{2} 10^{4}\end{array}$ & 2460 & 630 & 340 & 220 & 20 & 5 & 2,8 & 1,8 \\
\hline \multirow[t]{3}{*}{ 3. Довжина панелі, м } & 1,2 & 0,315 & 0,17 & 0,11 & 0,01 & 0,0025 & 0,0014 & 0,0009 \\
\hline & \multicolumn{8}{|c|}{ Температура в об'ємі ДНК $-70^{\circ} \mathrm{C}$} \\
\hline & \multicolumn{8}{|c|}{ Втрати тепла через ізоляцію $-8,8$ Вт } \\
\hline $\begin{array}{l}\text { 1. Коефіцієнт тепловіддавання } \\
\text { від панелі до ДНК, Вт/м² } \cdot \text { К }\end{array}$ & 4,2 & 5,5 & 6,2 & 6,8 & 599 & 789 & 896 & 975 \\
\hline $\begin{array}{l}\text { 2. Необхідна поверхня панелі, } \\
\mathrm{m}^{2} \cdot 10^{4}\end{array}$ & 4190 & 1070 & 560 & 370 & 29 & 7,4 & 3,9 & 2,6 \\
\hline \multirow[t]{3}{*}{ 3. Довжина панелі, м } & 2,10 & 0,535 & 0,280 & 0,185 & 0,015 & 0,004 & 0,002 & 0,001 \\
\hline & \multicolumn{8}{|c|}{ Температура в об'ємі ДНК - $100{ }^{\circ} \mathrm{C}$} \\
\hline & \multicolumn{8}{|c|}{ Втрати тепла через ізоляцію - 14,0 Вт } \\
\hline $\begin{array}{l}\text { 1. Коефіцієнт тепловіддавання } \\
\text { від панелі до ДНК, Вт/м²·К }\end{array}$ & 4,1 & 5,4 & 6,1 & 6,7 & 719 & 948 & 1077 & 1171 \\
\hline $\begin{array}{l}\text { 2. Необхідна поверхня панелі, } \\
\text { м² }^{2} 10^{4}\end{array}$ & 6820 & 1720 & 910 & 600 & 39 & 9,8 & 5,2 & 3,4 \\
\hline 3. Довжина панелі, м & 3,41 & 0,86 & 0,455 & 0,300 & 0,02 & 0,005 & 0,003 & 0,002 \\
\hline
\end{tabular}


Аналіз таблиці 3 показує, що при заповненні ДНК водою проблем для ії̈ підігріву не буде. При висоті нагрівальної панелі 20 см достатньо мати ширину $2 \ldots 3$ см. Однак при цьому не враховується перемішування за об'ємом камери, у зв'язку з чим ширину панелі слід виконувати $20 . .25$ см. У разі використання у якості середовища повітря довжина панелі зростає і при малих перепадах температур між панеллю та повітрям може становити 3,41 м.

У зв'язку з цим слід при роботі на повітрі забезпечувати якомога більший перепад температур. Так, при перепаді температур $25 . .35{ }^{\circ} \mathrm{C}$ при температурі в об'ємі ДНК $70{ }^{\circ} \mathrm{C}$ довжина панелі становитиме $0,280 \ldots 0,185$ м, що цілком прийнятно в конструкції камери. При температурі в обсязі ДНК $50{ }^{\circ} \mathrm{C}$ ця величина складе $0,11 \ldots 0,17$ м.

При розробці комбінованого холодильного агрегату з ДНК важливо оцінити втрати тепла від робочого тіла ДНК до навколишнього повітря у разі відключення додаткового нагрівача або відключення холодильника.

I цьому випадку буде спостерігатися нестаціонарний процес охолодження повітря чи води через ізоляцію ДНК.

Проведемо розрахунок нестаціонарного процесу охолодження для води та для повітря.

Мінімальний характерний розмір камери становить 0,33 м.

Визначимо коефіцієнт теплопередачі від робочого тіла в камері до навколишнього повітря. При розрахунку будемо використовувати результати, подані у таблиці 3.

Коефіцієнт теплопередавання дорівнює

$$
K=\frac{1}{\frac{1}{\alpha_{1}}+\frac{\delta_{\mathrm{i3}}}{\lambda_{\mathrm{i} 3}}+\frac{1}{\alpha_{2}}},
$$

де $\alpha_{1}$ та $\alpha_{2}$ - коефіцієнти тепловіддавання, відповідно, від внутрішнього об'єму до ізоляції та від ізоляції до зовнішнього повітря, Вт $/ \mathrm{M}^{2} \cdot K ; \delta_{\text {iз }}$ - товщина ізоляції.

Для повітря:

$$
K=\frac{1}{\frac{1}{7}+\frac{0,08}{0,02}+\frac{1}{7}}=0,23 \mathrm{BT} / \mathrm{M}^{2} \cdot \mathrm{K} .
$$

Для води:

$$
K=\frac{1}{\frac{1}{800}+\frac{0,08}{0,02}+\frac{1}{7}}=0,24 \mathrm{BT} / \mathrm{M}^{2} \cdot \mathrm{K} .
$$

Критерій Біо:

$$
B i=\frac{K \cdot \delta}{\lambda},
$$

де $\delta$ - половина лінійного розміру ДНК, $\delta=0,165$ м.

Критерій Фур'є

$$
F_{0}=\frac{\alpha \cdot \tau}{\delta^{2}}
$$

Теплофізичні характеристики [17]:

$$
\text { Повітря }
$$

Води

$$
\begin{array}{cc}
\lambda=0,0296 \mathrm{BT} / \mathrm{M} \cdot \mathrm{K} ; & \lambda=0,668 \mathrm{BT} / \mathrm{M} \cdot \mathrm{K} ; \\
\alpha=28,6 \cdot 10^{-6} \mathrm{~m}^{2} / \mathrm{c} & \alpha=16,3 \cdot 10^{-8} \mathrm{M}^{2} / \mathrm{c}
\end{array}
$$

Критерій Біо для повітря:

$$
B i=\frac{0,23 \cdot 0,165}{0,0296}=1,28
$$

для води:

$$
B i=\frac{0,24 \cdot 0,165}{0,668}=0,06
$$

Результати розрахунків температури в середині ДНК наведено у таблиці 4.

Таблиця 4 - Температура в обсязі ДНК

\begin{tabular}{|c|c|c|c|c|c|c|c|}
\hline \multicolumn{5}{|c|}{ Повітря } & \multicolumn{5}{c|}{ Вода } \\
\hline \multicolumn{7}{|c|}{ Час, хв } & \multicolumn{5}{c|}{ Час, хв } \\
\hline 1 & 5 & 10 & 15 & 1 & 15 & 30 & 60 \\
\hline \multicolumn{7}{|c|}{ Початкова температура ДНК $-50^{\circ} \mathrm{C}$} \\
\hline 50 & 44 & 38 & 34 & 50 & 49,5 & 48,5 & 47,9 \\
\hline \multicolumn{7}{|c|}{ Початкова температура ДНК - 70 ${ }^{\circ} \mathrm{C}$} \\
\hline 70 & 60 & 50 & 42 & 70 & 67,5 & 66,5 & 65,0 \\
\hline
\end{tabular}

Аналіз таблиці 4 показує, що у разі використання у якості робочого тіла ДНК повітря, його охолодження йде в 32 рази швидше, ніж у випадку 3 водою при початковій температурі $50{ }^{\circ} \mathrm{C}$, а при початковій температурі $70^{\circ} \mathrm{C}$ - швидше 11 раз. 
3 цього можна дійти висновку, що при використанні ДНК для нагрівання води ізоляція може бути частково зменшена.

\section{3. Висновки}

На підставі результатів проведених досліджень зроблено такі висновки:

1. Теплова потужність, що відводиться в процесі проведення випробувань АХА з ДФТС, закріпленого на підйомній магістралі дефлегматора, не перевищувала 7 Вт, а в середньому становила 4...5 Вт.

2. Величини теплового потоку, що відводиться 3 дефлегматора AXА за допомогою ДФТС, достатньо тільки для підтримки в ДНК температури на рівні $50{ }^{\circ} \mathrm{C}$,

3. Для підтримки в ДНК рівня температур $70{ }^{\circ} \mathrm{C}$ та $100{ }^{\circ} \mathrm{C}$ потрібні додаткові енерговитрати.

4. Величина додаткових енерговитрат для $70{ }^{\circ} \mathrm{C}$ становить 3,5 Вт, а для $100{ }^{\circ} \mathrm{C}-8,7$ Вт. При цьому добові енерговитрати холодильника зростуть відповідно на $4,9 \%$ та $12,3 \%$.

5. При повному використанні теплоти дефлегмації для обігріву ДНК можливе забезпечення iï теплових режимів у діапазоні температур $50 \ldots 100^{\circ} \mathrm{C}$.

6. У разі використання у якості робочого середовища ДНК повітря, виникають проблеми при теплопередаванні від конденсатора ДФТС до внутрішнього об'єму камери. У цьому випадку необхідно підтримувати перепад температур між нагрівальною панеллю i повітрям в ДНК близько $25 . .35^{\circ} \mathrm{C}$, а величина панелі повинна становити не менше $0,200 \times 0,285$ м (висота $\times$ ширина).

7. У разі використання води у якості робочого середовища ДНК доцільно використовувати нагрівальні панелі висотою 0,2 м, шириною 0,02...0,03 м. Для інтенсифікації процесів теплопередавання при нагріванні води, нагрівальну панель необхідно розташовувати в нижній частині ДНК.

8. У разі використання повітря в ДНК, його охолодження через втрату тепла до навколишнього повітря йде в 32 рази швидше, ніж при використанні води при початковій температурі $50{ }^{\circ} \mathrm{C}$ і в 11 разів швидше при початковій температурі $70^{\circ} \mathrm{C}$.

\section{Особистий внесок авторів CRediT}

Гратій T.І.: перевірка, візуалізація, програмне забезпечення, написання - огляд та редагування.
Тітлов О.С.: концептуалізація, методологія, дослідження, формальний аналіз, написання - оригінальний проект, адміністрування.

\section{Література}

1. Чернышев В.Ф., Хоменко Н.Ф., Титлов А.С. Вольневич С.В. Новые конструкции АБХ // Холодильная техника. - 1991. - № 12. - С.12-13.

2. Титлов А.С. Новое направление развития бытовой холодильной техники // Тепловые режимы и охлаждение радиоэлектронной аппаратуры. 1993. - № 2. - С. 61-63.

3. Titlov A.S., Rybnikov M.V. Tendenzen der Entwicklung von Hauschalts-Kugl-und Gefriegeraten in der Ukraine und Untersuchungen neuer Arbeitsverfahren // Die Kalte und Klima-technik. - 1994. - № 6. - S. 386-388.

4. Титлов А.С., Васылив О.Б. Разработка нового типа бытовых аппаратов // Холодильное дело. 1997. - № 3. - C. 21.

5. Титлов А.С. Аппараты для комбинированной термической обработки пищевых продуктов // Аграрная наука. - 1997. - № 5. - С. 42-43.

6. Васылив О.Б., Титлов А.С., Оргиян А. А. Моделирование тепловых режимов нагревательных камер комбинированных бытовых аппаратов абсорбционного типа // Холодильная техника и технология. - 2003. - № 2. - С. 13-18.

7. Чернышов В.Ф., Двирный В. В., Титлов А. С., Овечкин Г. И., Смирнов-Васильев К. Г., Хоменко Н.Ф., Демтиров В.Х., Григоров Г.И., Олифер Г.М. Патент 1814008 Российская Федерация, МПК5 F 25 D 11/02. Комбинированный абсорбционный холодильник. - № 4890428/06; заявл. 13.12.90; опубл. 07.05.93, Бюл. № 17.

8. Чернышов В.Ф., Двирный В. В., Титлов А. С., Овечкин Г. И., Смирнов-Васильев К. Г., Хоменко Н.Ф., Демтиров В.Х., Григоров Г.И., Олифер Г.М. Патент 1814006 Российская Федерация, МПК5 F 25 D 11/02. Комбинированный абсорбционный холодильник. - № 4890425/06 ; заявл. 13.12.90 ; опубл. 07.05.93, Бюл. № 17.

9. Титлов А. С., Чернышов В.Ф., Двирный В. В., Овечкин Г. И., Смирнов-Васильев К. Г., Хоменко Н.Ф., Олифер Г.М., Демтиров В.Х., Григоров Г.И. Патент 1814007 Российская Федерация, МПК5 F 25 D 11/02. Комбиниро-ванный абсорбционный холодильник. - № 4890427/06; заявл. 13.12.90 ; опубл. 07.05.93, Бюл. № 17. 
10. Тітлов О. С., Захаров М. Д., Василів О. Б., Вольневич С.В. Деклараційний патент № 47866А Україна, МПК7 F 25 D 11/02. Комбінований абсорбційний холодильник. - № 2001106933; заявл. 11.10.01; опубл. 15.07.02, Бюл. № 7.

11. Тітлов О. С., Захаров М. Д., Василів О. Б., Вольневич С.В. Деклараційний патент № 47751A Україна, МПК7 F 25 В 15/10. Комбінований абсорбційний холодильник. - № 2001096073; заявл. 04.09.2001; опубл. 15.07.02, Бюл. № 7.

12. Чернышов В.Ф., Овечкин Г. И., Титлов А. С., Смирнов-Васильев К. Г., Двирный В. В., Хоменко Н.Ф., Олифер Г.М. Патент 1835898 Российская Федерация, МПК5 F 25 D 11/00. Устройство для тепловой обработки и хранения продуктов. - № 4874603/13; заявл. 17.10.90 ; опубл. 06.06.94, Бюл. № 25.

13. Чайковский В.Ф., Тележенко Л.Н., Тельных
Э.Я., Вольневич С.В., Титлов А.С. Использование тепловой камеры комбинированного холодильника для обработки пищевых продуктов. Одесса: ОТИПП, 1991. - 22 с.

14. Прилади холодильні побутові. Експлуатаційні характеристики та методи випробувань: ДСТУ 3023-95 (ГОСТ 30204-95, ISO 5155-83, ISO 737185, ISO 8187-91). - Чинний від 1995-7-20. - К.: Держстандарт України, 1996. - 22 с. - (Національний стандарт України).

15. Богданов С.Н., Иванов О. П., Куприянова А. В. Холодильная техника. Свойства веществ. М.: Агропромиздат, 1985. - 208 с.

16. Исаев С.И., Кожинов Н.А., Кофанов В.И. и др. Теория тепломассобмена. - М.: Высшая школа, 1979. - 495 c.

Отримана в редакції 28.08.2021, прийнята до друку 01.10.2021

\title{
Development of devices for primary heat treatment and refrigerated storage of food products
}

\author{
Tetiana Hratii ${ }^{1}$, Oleksandr Titlov ${ }^{{ }^{2}}$ \\ ${ }^{1-2}$ Odessa National Academy of Food Technologies, 112 Kanatna str., Odessa, 65039, Ukraine \\ $\triangle$ e-mail: ${ }^{2}$ titlov1959@gmail.com \\ ORCID: ${ }^{1}$ https://orcid.org/0000-0002-3525-8410; ${ }^{2}$ https://orcid.org/0000-0003-1908-5713
}

Experimental studies of combined refrigeration units of absorption type (ARU) with an additional heating chamber (AHC), which provides heat and refrigeration treatment of food in the home. A two-phase evaporative thermosyphon (TPTS) is used to provide thermal communication between the heat dissipating elements of ARA (reflux condenser). It is shown that the thermal power allocated in the process of ARU tests with TPTS, fixed on the lifting line of the reflux condenser, did not exceed $7 \mathrm{~W}$, and on average was $4 \ldots 5 \mathrm{~W}$; the magnitude of the heat flux dissipated from the ARU reflux condenser by TPTS is sufficient only to maintain the temperature in the $\mathrm{AHC}$ at $50{ }^{\circ} \mathrm{C}$; to maintain the DNA temperature of $70{ }^{\circ} \mathrm{C}$ and $100{ }^{\circ} \mathrm{C}$ requires additional energy consumption; the value of additional energy consumption for $70{ }^{\circ} \mathrm{C}$ is $3.5 \mathrm{~W}$, and for $100{ }^{\circ} \mathrm{C}$ $8.7 \mathrm{~W}$, while the daily energy consumption of the refrigerator will increase by $4.9 \%$ and $12.3 \%$, respectively; with full use of the heat of reflux for heating $A H C$, it is possible to ensure its thermal regimes in the temperature range of $50 \ldots 100{ }^{\circ} \mathrm{C}$; in the case of using $\mathrm{AHC}$ as the working medium, there are problems with heat transfer from the TPTS condenser to the internal volume of the chamber - in this case it is necessary to maintain the temperature difference between the heating panel and air in DNA about $25 \ldots 35{ }^{\circ} \mathrm{C}$ and the panel size should be not less than $0.200 \times 0.285 \mathrm{~m}$; in the case of using water as a working medium for AHC, it is advisable to use heating panels $0.2 \mathrm{~m}$ high, $0.02 \ldots 0.03 \mathrm{~m}$ wide, and to intensify heat transfer processes when heating water, the heating panel must be located at the bottom of the AHC; in the case of using air in AHC, its cooling due to heat loss to the ambient air is 32 times faster than when using water at an initial temperature of $50^{\circ} \mathrm{C}$ and 11 times faster at an initial temperature of $70{ }^{\circ} \mathrm{C}$.

Keywords: Absorption refrigeration unit; Additional heating chamber; Two-phase evaporating thermosyphon; Utilization of waste heat of the refrigeration cycle; Experimental studies 


\section{References}

1. Chernyshev, V.F., Khomenko, N.F., Titlov, A.S. Volnevich, S.V. (1991) New designs of ABH. Kholodilnaya tekhnika, 12, 12-13.

2. Titlov, A.S. (1993) A new direction in the development of household refrigeration equipment. Teplovye regymy $i$ okhlazdenie radioelektronnoi apparatury, 2, 61-63.

3. Titlov, A.S., Rybnikov, M.V. (1994) Tendenzen der Entwicklung von Hauschalts-Kuglund Gefriegeraten in der Ukraine und Untersuchungen neuer Arbeitsver-fahren. Cold and air conditioning technology, 6, 386-388.

4. Titlov, A.S., Vasyliv, O.B. (1997) Development of a new type of household appliances. Kholodilnoe delo, 3, 21 .

5. Titlov, A.S. (1997) Apparatus for combined heat treatment of food products. Agrarnaya nauka, 5, 42-43.

6. Vasyliv, O.B., Titlov, A.S., Orgiyan, A.A. (2003) Modeling of thermal modes of heating chambers of combined household appliances of absorption type. Kholodilnaya tekhnika I tekhnologiya, 2, 13-18.

7. Chernyshov, V.F., Dvirny, V.V., Titlov, A.S., Ovechkin, G.I., Smirnov-Vasiliev, K.G., Khomenko, N.F., Demtirov, V.Kh., Grigorov, G I.I., Olifer, G.M. (1993) Patent 1814008 Russian Federation, MPK5 F 25 D 11/02. Combined absorption refrigerator. No. 4890428/06; declared 12/13/90; publ. 05/07/93, Bul. No. 17.

8. Chernyshov, V.F., Dvirny, V.V., Titlov, A.S., Ovechkin, G.I., Smirnov-Vasiliev, K.G., Khomenko, N.F., Demtirov, V.Kh., Grigorov, G I.I., Olifer, G.M. (1993) Patent 1814006 Russian Federation, MPK5 F 25 D 11/02. Combined absorption refrigerator. No. 4890425/06; declared 12/13/90; publ. 05/07/93, Bul. No. 17.

9. Titlov, A.S., Chernyshov, V.F., Dvirny, V.V., Ovechkin, G.I., Smirnov-Vasiliev, K.G., Khomen- ko, N.F., Olifer, G.M., Demtirov, V Kh., Grigorov, G.I. (1993) Patent 1814007 Russian Federation, MPK5 F 25 D 11/02. Combined absorption refrigerator. No. 4890427/06; declared 12/13/90; publ. 05/07/93, Bul. No. 17.

10. Titlov, O.S., Zakharov, M.D., Vasyliv, O.B., Volnevich, S.V. (2002) Declarative patent No. 47866A Ukraine, MPK7 F 25 D 11/02 Combined absorption refrigerator. № 2001106933; declared 11.10.01; publ. 15.07.02, Bull. № 7 .

11. Titlov, O.S., Zakharov, M.D., Vasyliv, O.B., Volnevich, S.V. (2002) Declarative patent No. 47751A Ukraine, MPK7 F 25 B 15/10. Combined absorption refrigerator. № 2001096073; declared 04.09.2001; publ. 15.07.02, Bull. № 7 .

12. Chernyshov, V.F., Ovechkin, G.I., Titlov, A.S., Smirnov-Vasiliev, K.G., Dvirny, V.V., Khomenko, N.F., Olifer, G.M. (1994) Patent 1835898 Russian Federation, MPK5 F 25 D 11/00. A device for heat treatment and storage of food. No. 4874603/13; declared 10.17.90; publ. 06.06.94, Bul. No. 25.

13. Tchaikovsky, V.F., Telezhenko, L.N., Telnykh, E.Ya., Volnevich, S.V., Titlov, A.S. (1991) Using the thermal chamber of the combined refrigerator for food processing. Odessa: OTIPP, 22.

14. Household refrigerating appliances. Performance characteristics and test methods (1996): DSTU 302395 (GOST 30204-95, ISO 5155-83, ISO 7371-85, ISO 8187-91). Valid from 1995-7-20. Kyiv: State Standard of Ukraine, 22. (National standard of Ukraine).

15. Bogdanov, S.N., Ivanov, O.P., Kupriyanova, A.V. (1985) Refrigeration equipment. Properties of substances. Moscow.: Agropromizdat, 208.

16. Isaev, S.I., Kozhinov, N.A., Kofanov, V.I. et al (1979) Heat and mass transfer theory. Moscow: Higher school, 495.
Received 28 August 2021

Approved 01 October 2021

Available in Internet 15 October 2021 